\title{
THE JUDICIARY AND THE BAR IN INDIA DURING THE EMERGENCY
}

\author{
By A. G. NOORANI
}

The Janata Party Government's assumption of power in March 1977 marked the restoration of the democratic process and the rule of law in India. It initiated, predictably, a series of post-mortems about the performance of various political parties, groups, professions, organisations and individuals during the nineteen months of trial from June 26, 1975 till January 18, 1978 when Mrs. Indira Gandhi announced her decision to hold elections and released political prisoners and lifted censorship of the press. At a Seminar held in New Delhi in November 1977, under the joint auspices of the International Press Institute and Friedrich Naumann Stiftung, the Minister for Information and Broadcasting, Mr. L. K. Advani said that the legal profession fared the best and the journalists the worst during the emergency. ${ }^{1}$ The opinion which Mr. Jayaprakash Narayan expressed about the judiciary during the emergency itself represents a fair verdict. "As for the judiciary, I must say that the High Courts have come out with flying colours in the present crisis. But the record of the Supreme Court is unfortunately very disappointing, mainly because Mrs. Gandhi has packed it with pliant and submissive judges except for a few."' J. P., as he is affectionately called, hat hit the nail on the head. In a very real sense the judicial crisis of April 1973 caused by the supersession of three of the senior most judges in the appointment of the Chief Justice of India hat alerted the Bar and demoralised the Supreme Court. ${ }^{3}$ As a matter of fact the Bar was as well equipped to face an internal dictatorship as it was to combat alien rule.

The progress of India's march to freedom under British rule was registered by successive Acts of the British Parliament culminating in the Indian Independence Act, 1947. Lawyers were uniquely qualified to strive to hasten this process as well as that of liberalisation of the law of sedition and the press laws. Likewise, during the emergency. It was proclaimed under the Constitution and its main instrument was the Defence of India \& Maintenance of Internal Security Act, 1971 and the Rules made thereunder. It was the Act and the Rules which empowered the Government of India to ban public meetings and impose press censorship. The Maintenance of Internal Security Act, 1971 (MISA) empowered it to detain persons without trial, through "preventive detention", by executive order. Amendments to the Act during the emergency ousted judicial review. Here, again, lawyers were peculiarly qualified to meet this situation. One of the first challenges was a resounding success. On July 24, 1975, Mr. Kuldip Nayar of "The Indian Express" was arrested and detained under MISA. His wife, Mrs. Bharati Nayyar, filed a habeas corpus petition in the Delhi High Court. Mr. V. M. Tarkunde argued the petition on her behalf. He had won national attention already by then for his courageous opposition to the emergency. A former Judge of the Bombay High Court, he was a Senior Advocate in the Supreme Court and Secretary of a non-party organization established by J. P. in 1974 called "Citizens for Democracy" besides being editor of a monthly "Radical Humanist". Within a few days of the proclamation of emergency he wrote an article entitled "Scope of the Pre-Censorship Order" in which he argued that de-

\footnotetext{
1. The Sunday Standard, November 27, 1977.

2. Pcople edited by N. G. Goray; Pune; September 15, 1976; page 36.

3. For details Vide Mr. S. S. Sen's article "Constitutional Storm in India", VRU 1974 pp. 33-43.
} 
spite the Order, under the DIR, newspapers were free to comment on the justification or otherwise of the Emergency or of the censorship. The article was not published but its copies were distributed and inspired later legal challenges to the Order.

The Delhi High Court accepted Mrs. Nayyar's petition and quashed her husband's detention order on September 15, 1975. ${ }^{4}$ It was a truly erudite judgment which Mr. Justice S. Rangarajan delivered with the concurrence of his colleague Mr. Justice R. N. Aggarwal. They observed "There has been no suspension of the writ of Habeas Corpus (Article 226) in India. Personal liberty is sought to be regulated by law. If freedom from arbitrary or illegal arrests and prevention of exploitation of it for personal ends has to be made possible, it can be only by resort to the judicial power in order to keep administrative discretion in this respect 'structured, confined and checked', in the insightful language of Prof. K. C. Davis' 'Discretionary Justice'. It has been so aptly said (by John P. Roche, "Judicial Self-Restraint", American Political Science Review, Vol. 49, p. 772 (Sept. 1955)) that the judicial power and self-restraint are but two sides of the same coin; in fact they mutually support, do not destroy, each other. But if self-abnegation is allowed to masquerade as self-restraint that may also amount to allowing self-restraint to destroy the judicial power. It is this needed and delicate balance that has to be sought by the exercise of judicial power. It is in the light of such ideas, which we regard as basic to the functioning of the rule of law in our democracy, that we have endeavoured to understand the relevant constitutional and legislative provisions made during this emergency."

In Mr. Kuldip Nayyar's case, the State refused to produce the material in support of the detention before the Court and lost. MISA was thereafter amended to forbid the disclosure of such material.

The next important challenge to the emergency laws mounted by the lawyers was the Nathwani Case. It challenged the ban on meetings in Bombay. In view of the great importance of this case it is necessary to describe its background. Under the auspices of the "Citizens for Democracy", the All-India Civil Liberties Conference was held in Ahmedabad on October 12, 1975, presided over by Mr. J. C. Shah, a former Chief Justice of India. Lawyers predominated in the Conference. The speakers pulled no punches. In his inaugural speech, $\mathrm{Mr}$. M. C. Chagla, a former Chief Justice of Bombay and one of the leaders of the Supreme Court Bar in the last decade or so, refuted Mrs. Gandhi's charge that the Opposition hat conspired to overthrow her Government. He said, "There was no conspiracy on the part of the Opposition leaders. The conspiracy was by the Prime Minister. I repeat, the conspiracy was by the Prime Minister to put the leaders in jail, to have Press censorship and to deprive the people of India of their civil liberties." The Conference passed resolutions condemning the arbitrary arrests and the censorship order and demanded the revocation of the proclamation of the Emergency, the release of the detenues, the restoration of civil liberties and the holding of a general election to the Lok Sabha "before the first week of March 1976."

Ahmedabad was chosen as the venue of the Conference because it is the capital of Gujarat, a State then ruled by Mrs. Gandhi's political opponents. Mr. N. P. Nathwani, a former Judge of the Bombay High Court, took the battle to Bombay, capital of Maharashtra, which was governed by the Congress Party. Heformed a Committee of Lawyers for Civil Liberties and convened a private meeting to be held at the Jinnah Hall on October 18, 1975 to discuss "Civil Liberties and the Rule of Law under the Constitution." Mr. J. C. Shah, Mr. M. C. Chagla and Mr. Nathwani were to be the principal speakers. Not only did the Commissioner of Police refuse permission for a meeting of lawyers confined to the invitees, but the State

4. Criminal Writ No. 121 of 1975. 
Government passed a special Order under the DIRs banning the holding of any public meeting where the Emergency was to be discussed or even referred to except after the prior permission of the authorities. Mr. Nathwani and the office bearers of the Committee formally sought the permission. On its refusal they filed a writ petition in the Bombay High Court under Article 226 of the Constitution.

The case made legal history. 157 lawyers led by Mr. N. A. Palkhivala appeared for the petitioners. The Court allowed the petition declaring that "the petitioners have a right to hold the meeting of lawyers restricted to invitees and to discuss the matters regarding civil liberties and the rule of law which was proposed to be held on October 18, 1975. Such right to hold the meeting can be exercised at the time and on the date to which such meeting is adjourned in view of the pendency of this petition." The orders refusing permission were also quashed. ${ }^{5}$ The case was heard by Chief Justice R. M. Kantawala and Mr. Justice V. D. Tulzapurkar. In his concurring judgment the latter Judge made this forthright pronouncement, "Therefore even during the Emergencies that are currently in operation it is legitimate for any citizen to say that the proclamations of Emergency, which are legislative acts on the part of the President are unjustified or unwarranted; it is legitimate for any citizen to say that these Emergencies are being kept alive for suppressing democratic dissent and criticism and that these should be ended; it is legitimate for any citizen to say that the Presidential Order dated June 27,1975 , which in its blank form purports to take away the remedy by way of habeas corpus to challenge his detention even if it is made mala fide be revoked; and it is further legitimate for any citizen to say that Parliament should meet to disapprove the Proclamation and the Presidential Order dated June 27, 1975. Of course, all these things could be said by any citizen subject to one proviso that the manner in which all this is said by him does not constitute a 'pre-judicial act' as defined in Rule 36 (e) of Defence and Internal Security of India Rules, 1971 which according to the settled law of this country means that while saying all these things there should be no incitement to violence. . . In other words, creation of public opinion against the emergency in a pursuasive, peaceful and constructive manner is permissible and perfectly legal. Secondly, the importance of right to dissent in a democratic set up has been recognised in judicial decisions also, to some of which I may make a reference. In Anant Janardhan v. M. A. Deshmukh (68 Bombay Law Repeater 256) which was a case dealing with the freedom of press this Court at p. 273 of the report has observed thus: . . It is implicit in the freedom of press that every one ought to have the privilege of expressing opinions which are unpopular or distasteful. Right to dissent is the very essence of democracy. Conformity to accepted forms and belief has always been the enemy of freedom of thought." A clear judicial endorsernent of the right to criticise the emergency was precisely what was needed but, unfortunately, when the State of Maharashtra appealed to the Supreme Court the Court granted an unusual stay. Not only the High Court's operative order but even its judgment, the legal pronouncement, was stayed. All the same, it was followed by another Bench of the High Court in a censorship case ${ }^{6}$ in which it considered the scope of the censorship Order. The Court ruled that the fundamental right to freedom of speech and expression mentioned in Art. 19 (1) (a) of the Constitution is not a right created or conferred for the first time in the laws of India by Art. 19 (1) (a). It is a right under the Common Law of England which has been recognised and enforced by the Courts in India prior to the coming into force of the Constitution, and it has been continued in force by the Constitution.

The purpose for which the Censorship Order was made as mentioned in its preamble are

5. N. P. Nathwani vs. Commissioner of Police (1976) 78 Bombay Law Reporter 1.

6. Binod Rao vs. M. R. Masani 78 Bom. L. R. 125. 
only three, namely, (1) securing the defence of India and civil defence, (2) the public safety and (3) maintenance of public order. Whatever affects the internal security of the State affects the security of the State, public safety and public order. The omission of the words "the internal security" from the preamble of the Censorship Order does not, however, make any difference to the position, for whatever effects internal security must necessarily affect public safety and public order the Count ruled. The censorship Order, therefore, operates for the purpose of internal security, as it does for the other purposes mentioned in the preamble. Having thus limited the scope of censorship, the Court proceeded to remark "There is another important factor which the censor must also bear in mind. The press is not only an instrument of disseminating information but it is also a powerful medium of moulding public opinion by propaganda. True democracy can only thrive in a free clearing-house of competing ideologies and philosophies - political, economic and social - and in this the Press has a important role to play. The day this clearing-house closes down would toll the death-knell of democracy. It is not the function of the censor acting under the Censorship Order to make all newspapers and periodicals trim their sails to one wind or to tow along in a single file or to speak in chorus with one voice. It is not for him to exercise his statutory powers to force public opinion in a single mould or to turn the Press into an instrument of brain-washing the public. Under the Censorship Order the censor is appointed the nurse-maid of democracy and not its grave-digger. Dissent from the opinions and views held by the majority and criticism and disapproval of measures initiated by a party in power make for a healthy political climate, and it is not for the censor to inject into this the liefelessness of forced conformity. Merely that dissent, dissaproval or criticism is expressed in strong language is no ground for banning its publication, for as Sir Maurice Gwyer said in Niharendu Dutt Majumdar v. The King Emperor, (1942) F. C. R. 38 at p. 51, 'hard words break no bones . . . and there are certain words and phrases which have no long become the stock in trade of the demagogue as almost to have lost all real meaning.' But there are permissible limits to dissent and disapproval. The voice of dissent cannot take the form of incitement to revolutionary or subversive activities, for then instead of serving democracy it would subvert it. It is here that the censor's real role begins; for, though it is not for him to stiffle all dissent and protest, it is certainly his duty to see that dissent and protest do not overstep the permissible limits." This judgment and the Court's order quashing censor's decisions shared the same fate of an unusual stay by the Supreme Court.

So did a judgment of the Gujarat High Court. The authorities had issued a notice to the editor and printer of a journal which had published Mr. Chagla's speech at the Ahmedabad Conference to show cause why copies of the journal and the press itself should not be forfeited. The Court struck down the notices as invalid and opined that the speech was not objectionable. It made some strong observations about censorship as it was under operation "The guidelines issued by the Chief Censor take a further stride and place a blanket ban on the publication of news, views, criticism and comments, however peaceful and orderly they may be, if they are distasteful to the party in power. We feel unhappy to state that the guidelines issued by the Chief Censor completely choke the pipeline of democracy, fully contaminate the otherwise clean and invigorating environment of freedom and have a strong tendency to create a 'Managerial Class' for wire-fencing the people of this country in it. There cannot be a more Draconian assault on a people in a democracy than one which is disclosed by the guidelines issued by the Chief Censor. Whether we are passing through an emergency or living in normal times, whether the uncommon situation in the country requires placing of restraint on the freedom of people, the guidelines issued by the Chief Censor and quoted above can never be upheld. Public criticism which is the life-time of democr- 
acy is sought to be cut by these guidelines and they pierce into its heart. To permit such guidelines to operate even for a moment more will be destructive of our cherished democratic social order. We are, therefore, of the opinion that such of the guidelines as have no reference whatsoever or relation with the statutory purposes specified in Rule 48 or Section 3 are illegal and inoperative. Our decision on the vires of the statutory order produces this impact upon the guidelines. It is on account of this reason that we have stated in the earlier part of this judgment that the Chief Censor has been more loyal to the king than the king himself and has outwitted the people in their attempt to maintain even the basic form of democracy in this country ...."7

Mention must be made of another case. In the early morning of August 29, 1975, three boys, about 15 years old, were found by the police to be in possession of 48 leaflets containing the news bulletin issued by the Lok Sangharsha Samiti (People's Struggle Society). It contained a report of the speech by Mr. Mohan Dharia, M. P., in the Lok Sabha condemning the emergency and some news items. They were promptly arrested by the police. Their case was not different from that of thousands of others imprisoned in similar circumstances. But it had a strange sequel. They applied for bail pending investigation and trial to the magistrate, to the Seesions Judge, and, eventually, to the Nagpur Bench of the Bombay High Court. Mr. Justice U. R. Lalit ordered their release on bail on October 6, 1975. Rule 184 of the Defence of India Rules forbade grant of bail to anyone accused of a breach of the Rules unless the Court was satisfied "that there are reasonable grounds for believing that he is not guilty of such contravention." The Judge had perforce to consider whether the leaflet contained a "prejudicial report" whose circulation was an offence under the Rules. The expression had the same import under the DIR as the offence of sedition has under the Penal Code. The Judge held that the leaflets were not seditious and released the boys on bail. This judgment ${ }^{8}$ was cited as a precendent in magistrates' courts and helped to secure the release of many a dissenter. Unfortunately, these victories were nullified by the Supreme Court after a promising start. Mrs. Indira Gandhi's election to the Lok Sabha in 1971 was set aside by the Allahabad High Court on June 12, 1975, a fortnight before the emergency was proclaimed. She appealed to the Supreme Court. After the emergency was proclaimed not only was the electoral law amended retrospectively in her favour, on the points she had lost, but the Constitution 39th Amendment Act was enacted. One of its provisions (Art. 329 [4]) nullified the judgment and the election law. The Act created a special forum to try election petitions against the President, Vice-President, the Speaker and the Prime Minister. No such body was in fact created. The object was clearly to kill the proceedings against Mrs. Gandhi in a legal vacuum. The Supreme Court struck down Art. 329 A (4) as violative of the "basic structure" of the Constitution. ${ }^{9}$ The election was upheld only because the electoral law had been amended. By implication the Court reaffirmed the doctrine of an unamendable basic structure of the Constitution propounded by the Court in 1973 in Keshavananda Bharati's Case. ${ }^{10}$ A few days after the judgment on Mrs. Gandhi's election appeal a full Bench of the Court was constituted to review and to discard the doctrine. Thanks to Mr. Palkhivala's able advocacy, the effort failed and the Bench was dissolved on November 12, 1975 without any reason being assigned.

7. C. Vaidya vs. D'Penha S.C.A.No. 141 of 1976.

8. Sunil W. Sarodi vs. State of Maharashtra Cr. A. No. 298 of 1975.

9. Indira Nehru Gandhi vs. Raj Narain AIR 1975, Supreme Court 2295.

10. AIR 1973 S. C. 1461. 
Unfortunately, the victories won by the citizen in the High Courts were set at nought by the Supreme Court's judgment on April 28, 1976 in the Habeas Corpus Case. ${ }^{11}$ The Court ruled by a majority of 4 to 1 that in view of the President's Order of June 27, 1975 under Art. 359 of the Constitution suspending for as long as the emergency lasted the right to move any court for the enforcement of the fundamental rights to equality before the law (Art. 14), to personal liberty (art. 21), and to protection against arbitrary arrest and detention (Art. 22), no person could move a High Court for a writ of habeas corpus challenging the legality of an order of detention. Not even on the ground that the order was violative of the MISA under which it purported to have been passed or "is illegal or is vitiated by mala fides or is based on extraneous considerations." Mr. Justice H. R. Khanna was the sole dissenter.

The Supreme Court's disastrous ruling overruled nine High Courts which had held in favour of the citizen. "The Supreme Court's judgment on the Habeas Corpus question has put out the last flickering candle of individual freedom. Mrs. Gandhi's dictatorship, both in its personalised and institutionalised forms, is now almost complete", Mr. Jayaprakash Narayan said on May 15, 1976. Mr. M. C. Chagla characterised the decision as "the worst in the history of the Supreme Court." Mr. V. M. Tarkunde, a former Judge of the Bombay High Court and a leading member of the Supreme Court Bar characterised it as "Judicial Suicide". He wrote: "The Supreme Court decision in the Habeas Corpus case, apart from being legally unsound, is fraught with the greatest harm to our people and our country. It makes a mockery of the very concept of justice. It is essential that the decision should not be allowed for long to tarnish the fair name and commendable record of the highest tribunal in the country."

The Court's logic that since the right to life and liberty was a creature of the Constitution it could be taken away by an Order made under the Constitution could and would have been extended to the right of free speech as well had not the elections been held in March 1977. Meanwhile the regime began using other methods to demoralise the judiciary. Mr. Justice Lalit of the Bombay High Court and Mr. Justice R. N. Aggarwal of the Delhi High Court were Additional Judges. Violating all precedent, the Government of India refused to confirm them as permanent Judges. In May 1976, unprecedented orders for the transfer of 16 High Court Judges were made by the President under Art. 222 without the consent of the Judges affected. The Gujarat High Court held the transfers to be invalid. ${ }^{12}$ The Supreme Court reversed the ruling on appeal. ${ }^{13}$ The Bar had voiced its protests against the transfers and the refusals to confirm the Additional High Court Judges.

Many lawyers had been arrested and put into prison during the emergency, most notably Mr. P. N. Lekhi and Mr. M. Raja Jois, now a Judge of the Karnataka High Court. In March 1976 some 200 chambers of lawyers practising in New Delhi's Tis Hazari courts, the largest complex of civil and criminal courts in the capital, were demolished without notice and 43 lawyers put in prison. An emergency meeting of the General Body of the Supreme Court Bar Association was held on March 30, 1976. It strongly condemned the demolitions and the arrests and demanded the restoration of the chambers and the release of the lawyers. It was a deliberate attempt by the Government to terrorise the Bar. A warrant under the MISA for the arrest of Mr. R. Jethmalani, Chairman of the Bar Council of India had been issued following his speech at the Palghat Lawyers Conference in Kerala on January 25, 1976. Lawyers in Bombay got together to challenge the order. While the proceedings were pending

11. Additional District Magistrate, Jabalpur vs. Shivkant Shukla AIR 1976 S. C. 1207.

12. S. H. Sheth vs. Union of India (1976) 17 Gujarat Law Reporter 1017.

13. Union vs. S. H. Sheth AIR 1977 S. C. 2328. 
the Supreme Court delivered the ruling in the Habeas Corpus Case which destroyed the basis of Mr. Jethmalani's petition. He left India the day after the Supreme Court's judgment. There remained but one last fight for the Bar - the preservation of the Constitution in the face of the attempts to alter it in an authoritarian frame. Shortly after the imposition of the Emergency the Government of India revealed its intentions in regard to the Constitution. The Law Minister hinted at it in the Rajya Sabha on August 6, 1975. The next day he told the Lok Sabha that "the time has now come when we have to have a fresh look at the whole fundamental structure of the Constitution itself. The Constitution was framed years back when the situation was different. It was a document as a result of the compromise of different forces existing at that time." He emphasised that it was "a matter which has assumed grave urgency."14

In October a paper entitled "A Fresh book at our Constitution" was circulated with apparent official approval. It suggested a Presidential form of Government with a President enjoying virtually dictatorial powers. In the month following, an unsuccessful attempt was made to secure a rejection of the doctrine of "basic structure" by the Supreme Court. Undeterred, the Congress Party's President appointed on February 26, 1976 a Committee headed by Mr. Swaran Singh to suggest amendments to the Constitution. It submitted brief reports on certain aspects. The 43rd Constitution Amendment Bill was based largely on those reports. It became law on January 3, 1977 as the Constitution (Forty-Second Amendment) Act, 1976 after having been passed by the Lok Sabha on November 2, 1976 and by the Rajya Sabha nine days later.

The legal profession vigorously agitated against these moves all though 1976 despite the handicaps of censorship and ban on public meetings. A heartening feature of the agitation was that it associated academicians, journalists, and other persons from diverse walks of life in the common cause. A meeting of some Opposition MPs and other public figures was held in Bombay on March 20, 1976 in which JP participated. It also set up a Committee to suggest amendments to the Constitution. Its Interim Report published on May 25, 1976 suggested, in complete contrast to the Swaran Singh Committee's first Report, changes designed to prevent authoritarianism in the country. Among its members were Mr. M. C. Chagla, Mr. Shanti Bhushan, now Law Minister in the Government of India, and Mr. V. M. Tarkunde. A National Seminar on Constitutional Amendments was held in New Delhi on October 16 and 17,1976 . It was attended by some of the country's leading lawyers as well as the leading politicians who happened to be out of jail. Its statement of consensus contained a powerful attack on the Amendment Bill.

The Bill was adopted by Parliament all the same. Only a fortnight after it came into force, Mrs. Gandhi went to the polls. The office of the Chief Justice of India fell vacant as a result of the retirement of Mr. Justice A. N. Ray. On January 28, 1977 Mrs. Gandhi appointed as Chief Justice Mr. Justice M. H. Beg who had displayed a singularly servile attitude towards her. The senior-most Judge Mr. Justice H. R. Khanna was superseded. This evoked widespread criticism and protest which could now be openly expressed since the ban on meetings and censorship of the press had been lifted.

Mrs. Gandhi hoped, no doubt, to "legitimise" her authoritarian regime in the March 1977 elections. Fate had willed otherwise. Democracy has been restored in India. The legal profession and the Judges of the High Courts emerge with great credit. One wishes one could say the same for the Supreme Court.

14. Lok Sabha Debates August 7, 1975, Fifth Series, Vol. LIV-No. 14; col. 59. 
Unfortunately, one cannot. In the last judgment of consequence to the citizen before Mrs. Gandhi lost, the Supreme Court went to the length of holding that the writ of habeas corpus could not issue even to secure compliance with the Jail Manual or for the barest minimum conditions in prison to which a political detenue is entitled as distinct from a convicted prisoner. But the Supreme Court wiped out this distinction on January 25, 1977 with Mr. Justice Beg blithely holding the power of preventive detention as one "completely protected from judicial serutiny". ${ }^{15}$

One of India's leading constitutional lawyers Mr. H. M. Seervai has commented on the Supreme Court's unfortunate record in the latter phase of the emergency. "Till we come to the Habeas Corpus Case, the attitude of the Supreme Court to preventive detention, even during an emergency, was almost impeccable. One would have thought that if the Supreme Court adopted that attitude during emergencies created by war or external aggression, the Supreme Court would more readily adhere to that attitude during an emergency created by 'internal disturbance.' However, in comparing two different periods of the Supreme Court's history, it is only fair to the Supreme Court to say that between 1964 - 66 and 1975 - 77 the climate had changed. What effect the change of climate produced on the Habeas Corpus Case, and its aftermath, is difficult to say. That task must be left to the historian of the Supreme Court in the hope that relevant materials for forming a judgment will be available to him, sooner or later. But the change was brought about by the following factors." 16 He cites four of them - the supersessions in 1973, the leaks about constitutional amendments "intended to shake judicial nerves", press censorship even of judgments of courts, and the "atmosphere of terror and fear" created by the mass arrests and maltreatment in prison.

The Supreme Court's record during the emergency had a sequel in early 1978 when a Memorandum signed by lawyers and public figures was presented to the President of India urging that the senior-most Judge Mr. Justice Y. V. Chandrachud, be not appointed as Chief Justice of India on the retirement of Mr. Justice Beg in February as he was one of the judges who had pronounced against the citizen in the Habeas Corpus Case. The memorialists lost. The Government of India preferred the easy course and appointed Mr. Justice Chandrachud as Chief Justice. But the last is not yet heard of the norms and procedures for appointing Judges of the Supreme Court.

15. Union of India vs. B. K. Gawde \& Ors. (1877) 1 Supreme Court cases. 834.

16. H. M. Seervai, The Emergency, Future Safeguards and the Habeas Corpus Case: A Criticism; N. M. Tripathi P. Ltd. Bombay; 1978; p. 75. 


\section{The Question of Ideology in Non-western Societies}

By BASSAM TiBI

In scientific as well as popular literature "ideology" is used synonymously with ideas. In the critique of ideology we can observe normative, subjectivist positions interpreting ideas institutionalized as norms as a determinant of social change. In addition we can observe materialist analyses treating ideologies within the framework of a base-superstructure scheme. The author doubts the usefulness of both approaches for the analysis of ideologies in non-Western societies. He pleads for an approach taking both the immanent structure of ideology and its relation to social evolution into account. In analysing ideologies in nonWestern societies, the researcher is faced with the problem that here ideologies are the product of a process of acculturation and are not simply to be explained from within the context of the autocthonous society. In view of this social reality, the author attempts to develop a different approach to non-western ideologies and concludes with a study of the dominant ideologies of the Middle East: Islam, Arab Nationalism, Arab Socialism, the Arab response to Marxism. In this way the problems of studying ideologies in non-western societies are illustrated. The author shows why the study of these ideologies must be located in two scientific disciplines: the sociology of development and international relations.

\section{The Judiciary and the Bar in India During the Emergency}

By A. G. Noorani

The Janata Party Government's assumption of power initiated a series of post-mortems about the performance of various groups during the emergency. It has been claimed that the legal profession fared the best and the journalists the worst. This appears to be a fairverdict as far as lawyers and High Courts are concerned, while the record of the Supreme Court, due to Indira Ghandi's court packing in 1973 (cf. Sen, Constitutional Storm in India, VRU 1974, p. 33 sq.) has been disappointing. The article discusses in detail the challenges to the emergency legislation by the legal profession, their successes in the High Courts and their frustration in the Supreme Court.

\section{Codes of Conduct for Multinational Corporations in the Light of the Interests of De- veloping Countries}

By AlPHONS STUdieR

The formulation of codes of conduct for multinational corporations is one of the most complex issues that has been discussed within the context of the New International Economic Order. This task covers, among others, the basic issues of balance of payments, technology transfer, employment, transfer prices, taxation and information disclosure which were primarily discussed by the Commission on Transnational Corporations that was created in 1974 under the auspices of the UN-Economic and Social Council. In spite of widespread expectations that such codes sould help to regulate the activities of multinational corporations in developing countries, it is sometimes feared these codes could quite on the contrary prove as ideological means to legitimate these activities. By and large, this objection is true for "weak" codes like the OECD-Guidelines. But on the other hand, codes which are formally binding legal instruments formulated in precise language could really help strengthening the 